\title{
Pengembangan Multimedia Interaktif Aksara Jawa untuk Sekolah Dasar
}

\author{
Satrio Agung Prabowo ${ }^{1}, \mathrm{Sumarmi}^{2}$, Cholis $\mathrm{Sa}^{\text {'dijah }}{ }^{3}$ \\ ${ }^{1}$ Pendidikan Dasar-Universitas Negeri Malang \\ ${ }^{2}$ Pendidikan Geografi-Universitas Negeri Malang \\ ${ }^{3}$ Pendidikan Matematika-Universitas Negeri Malang
}

\section{INFO ARTIKEL}

\section{Riwayat Artikel:}

Diterima: 25-03-2019

Disetujui: 13-08-2019

Kata kunci:
multimedia development;
javanese alphabet;
primary school;
pengembangan multimedia;
aksara jawa;
sekolah dasar

\section{Kata kunci:}

javanese alphabet;

primary school

aksara jawa;

\author{
Alamat Korespondensi: \\ Satrio Agung Prabowo \\ Pendidikan Dasar \\ Universitas Negeri Malang \\ Jalan Semarang 5 Malang \\ E-mail: Prabowo.satrioagung.sa@gmail.com
}

\begin{abstract}
ABSTRAK
Abstract: The purpose of the research and development that is producing a eligible interactive multimedia Javanese alphabet products with valid criteria, practical, interesting, and effective. This research and development using model Lee \& Owens. They use some following steps; (1) analysis assessment, (2) designs, (3) development, (4) implementation, and (5) evaluation. The results showed that interactive multimedia were very valid with an average percentage of $86,93 \%$, very practical with an average percentage of $89,83 \%$, very interesting with an average of $88,97 \%$. Interactive multimedia is also very effective, as evidenced by the results of the posttest for $91.66 \%$ of students who have received complete marks.

Abstrak: Tujuan penelitian dan pengembangan ini yaitu untuk menghasilkan multimedia interaktif aksara Jawa yang layak dengan memenuhi kriteria valid, praktis, menarik, dan efektif. Penelitian dan pengembangan ini menggunakan model dari Lee \& Owens. Tahapan pengembangan yaitu (1) analisis kebutuhan dan analisis awal-akhir, (2) desain, (3) pengembangan, (4) implementasi, dan (5) eveluasi. Hasil penelitian didapatkan bahwa multimedia interaktif sangat valid dengan rata-rata persentase $86,93 \%$, sangat praktis dengan rata-rata presentase $89,83 \%$, sangat menarik dengan rata-rata persentase $88,97 \%$. Multimedia interaktif ini juga sangat efektif dibuktikan dengan hasil posttest sebesar $91,66 \%$ siswa telah mendapatkan nilai tuntas.
\end{abstract}

Indonesia merupakan negara dengan budaya yang beragam. Terdapat beberapa unsur dalam budaya salah satunya adalah bahasa. Bahasa merupakan hal yang sangat penting digunakan sebagai alat komunikasi dalam suatu kelompok sosial. Bahasa juga dapat digunakan sebagai sarana untuk dapat mengungkapkan pikiran, baik secara lisan ataupun dengan menggunakan tulisan. Bahasa adalah sarana komunikasi yang dapat digunakan oleh orang untuk memberi dan menerima pesan dari orang lain. Selebihnya, bahasa adalah salah satu dari lambang kebanggaan dan merupakan identitas suatu daerah tertentu. Bahasa memegang peranan penting dalam kebudayaan suatu daerah. Ada banyak bahasa yang ada, salah satunya yaitu bahasa Jawa yang banyak digunkan di Indonesia. Hasil sensus (Badan Pusat Statistik, 2010) menegaskan bahwa suku Jawa adalah suku terbesar dengan proporsi 40,05\% dari jumlah penduduk Indonesia. Terdapat banyak nilai dalam bahasa Jawa, antara lain yaitu nilai-nilai tata karma dan sopan santun. Nilai tersebut harus terus dipelajari, dilestarikan, dan dikembangkan untuk dapat menjadi nilai-nilai positif yang berguna dalam kehidupan manusia.

Seiring berjalannya waktu, budaya yang ada sudah semakin terpinggirkan. Banyak dari generasi muda yang mulai tidak mengenali budayanya sendiri. Misalnya, pada saat ini banyak dari generasi muda suku Jawa yang sudah tidak menggunakan lagi bahasa Jawa. Mereka pada saat ini lebih banyak menggunakan bahasa Indonesia dan bahasa asing. Padahal dalam bahasa Jawa sendiri terdapat unsur unggah ungguh dalam berkomunikasi. Oleh karena itu, generasi muda khususnya suku Jawa sudah sepantasnya melestarikan bahasa Jawa demi kelangsungan dan tetap terjaganya bahasa Jawa. Apalagi bahasa Jawa merupakan bahasa dengan budi pekerti luhur, atau merupakan cerminan dari tata krama.

Bahasa Jawa merupakan salah satu dari beberapa yang merupakan bagian integral dari kebudayaan Indonesia. Bahasa Jawa sendiri telah tumbuh sebagai identitas diri dan tetap mempertahankan bagian-bagian nilai luhur yang banyak terkandung di dalamnya. Selain itu, dalam bahsa Jawa juga terdapat aksara Jawa didalamnya yang merupakan aksara asli dari suku Jawa. Aksara Jawa biasanya digunakan menulis bahasa Jawa itu. Bahasa Jawa dan aksara Jawa harus terus dijaga kelestarian dan keberadaannya. 
Bahasa Jawa biasa digunakan sebagai sarana untuk berkomunikasi, saling berbagi pengalaman, saling belajar, serta dapat digunakan untuk dapat meningkatkan kemampuan intelektual dan untuk apresiasi sastra (Arafik, 2013). Berbagai upaya dilakukan oleh pemerintah untuk tetap menjaga kelestarian bahasa Jawa. Di dalam UU RI No. 20 Tahun 2003, pasal 37 ayat 1 , disebutkan beberapa mata pelajaran yang wajib dimuat dalam kurikulum pendidikan dasar, salah satunya adalah muatan lokal.. Hal tersebut merupakan salah satu upaya revitalisasi pembelajaran Bahasa, Sastra, dan Jawa khususnya di lingkungan sekolah dasar (Tim Pengembang Kurikulum, 2010). Adanya kebijakan tersebut menimbulkan efek positif di tingkat pendidikan dasar dengan dialokasikannya jam pelajaran untuk pembelajaran Bahasa, Sastra, dan Budaya Jawa yaitu dua jam pelajaran setiap minggu.

Pada sekolah dasar saat ini pembelajaran muatan lokal Bahasa, Sastra, dan Budaya Jawa diarahkan agar siswa dapat menguasai dan memiliki kemampuan berkomunikasi menggunakan bahasa Jawa dengan baik dan benar, secara lisan maupun tulisan. Selain untuk tujuan pendidikan, juga untuk menumbuhkan apresiasi terhadap hasil karya sastra dan budaya Jawa (Tim Pengembang Kurikulum, 2010). Keberadaan mata pelajaran Bahasa Jawa juga merupakan salah satu langkah yang ditempuh untuk tetap melestarikan budaya Jawa.

Tujuan dari pembelajaran bahasa Jawa di sekolah dsar yaitu untuk meningkatkan aspek ketrampilan berbahasa, yang pertama yaitu ketrampilan mendengar, sedangkan yang kedua yaitu berbicara, yang ketiga yaitu membaca, yang keempat yaitu menulis, dan yang kelima yaitu apresiasi sastra (Djuwadi, 2016). Khusus untuk ketrampilan membaca dan menulis, tidak hanya diajarkan membaca dan menulis bahasa Jawa dalam huruf latin. Siswa juga harus menguasi ketrampilan membaca dan menulis dalam aksara Jawa. Berdasarkan hasil dari studi pendahuluan yang telah dilakukan oleh peneliti di SDN Kebonsari 2 Malang pada tanggal 19 Juli 2018 diketahui bahwa, proses pembelajaran Bahasa Jawa di Sekolah Dasar telah diajarkan sejak siswa mulai menginjak kelas I. Sementara itu, pembelajaran materi aksara Jawa baru mulai diajarkan kepada sisiwa kelas III. Pada saat kelas III tersebut masih memasuki tahap pengenalan saja.

Lebih lanjut dari hasil studi pendahuluan yang telah dilakukan oleh peneliti juga menemukan fakta bahwa hampir separuh siswa kelas V masih mengalami kesulitan untuk dapat lancar mempelajari aksara Jawa. Hal tersebut dikarenakan bentuk tilisan pada aksara Jawa ayang hampir sama, pelafalan, dan penyusunan beberapa aksaranya yang dianggap rumit. Selain itu pembelajaran yang biasa dilakukan dengan metode ceramah dan klasikal tanpa adanya pemanfaatan media juga dapat menjadi penyebab sulitnya siswa dalam memahami aksara Jawa. Hal tersebut sejalan dengan pendapat dari Nurlaili (2016) media yang digunakan untuk pembelajaran Bahasa Jawa pada saat ini tidak sebanyak media untuk pembelajaran lain. Media pembelajaran yang biasa digunakan untuk Bahasa Jawa hanya poster Aksara Jawa, buku penunjang pepak, dan wayang kulit. Sehingga hal tersebut kurang dapat menumbuhkan keaktifan dan ketertarikan bagi siswa. (Wiyoto, 2015) menjelaskan bahwa hasil belajar pun banyak ditentukan oleh motivasi. Dengan pemilihan dan penggunaan multimedia interaktif diharapkan membantu minat dan motivasi belajar siswa. Hal itu dapat dibuktikan berdasarkan hasil penelitian yang dilakukan oleh (Jusuf, 2009) yang berjudul "Perancangan Aplikasi Sistem Ajar Tematik Berbasis Multimedia", hasil penelitian ini menjelaskan bahwa dengan menggunakan multimedia dalam pembelajaran dapat membuat untuk meningkatkan minat dan motivasi belajar siswa.

Terdapat salah satu bentuk inovasi yang dapat dipilih untuk dapat menyelesaikan permasalahan pembelajaran aksara Jawa. Bentuk inovasi yang mungkin dapat dilakukan adalah dengan memanfaatkan perkembangan ilmu pengetahuan dan teknologi. Pada saat ini kemajuan teknologi yang terjadi dari tahun ke tahun semakin pesat dan canggih. Dahulu komputer dianggap sebagai peralatan mahal, sedangkan sekarang sudah menjadi alat yang biasa digunakan dalam kehidupan sehari-hari. Banyak dari siswa SD sekarang ini sudah tidak asing dan sudah terbiasa menggunakan perangkat komputer. Mereka hampir setiap hari sudah terbiasa mengoperasikan komputer untuk berbagai kegiatan. Mulai dari belajar, mencari informasi mengenai pelajaran, sampai bermain game.

Salah satu sumber belajar atau wahana fisik yang tidak terpisahkan dari proses pembelajaran adalah media pembelajaran. Dalam media pembelajaran biasanya mengandung beberapa materi instruksional sehingga dapat merangsang siswa untuk belajar. Dengan demikian, media pembelajaran diharapkan agar dapat memperlancar proses dalam interaksi antara guru dan siswa dalam memahami suatu materi yang dipelajari. Hal tersebut juga sesuai dengan hasil yang dilakukan oleh (Kusmayadi, 2017) media yang dikatakan telah sesuai adalah media yang membantu penggina dalam pembelajaran, bisa memudahkan siswa dalam pemahaman materi yang diajarkan, dan telah sesuai dengan kompetensi pembelajaran yang dipelajari. Dalam proses pembelajaran, guru hendaknya memiliki pengetahuan dan pemahaman yang cukup tentang media.

Adanya multimedia interaktif dalam pembelajaran dapat menjadikan proses selama pembelajaran dapat menjadi lebih efektif dan menyenangkan bagi siswa. Hal ini sesuai dengan beberapa penelitian sebelumnya, adanya multimedia interaktif siswa lebih cepat memahami materi pembelajaran, dan pembelajaran lebih menarik (Ramansyah, 2014), terdapat keterlibatan secara aktif minimal indera pendengaran dan penglihatan siswa sehingga dapat menarik perhatian siswa dan siswa lebih mudah memahami materi (Yumarlin, 2012) meningkatkan minat belajar siswa, dapat meningkatkan kualitas pembelajaran yang ditunjukkan dengan aktivitas pembelajaran yang sangat baik, hasil evaluasi pembelajaran yang sangat tinggi (Herijanto, 2012), menciptakan prosesbelajar yang interaktif dan menyenangkan (Batubara, 2015). 
Penggunaan multimedia interaktif pada dewasa ini sudah bukan lagi menjadi hal yang mengejutkan. Namun, masih banyak guru yang belum mampu mengembangkan multimedia interaktif untuk pembelajaran. Perlu diadakannya pelatihan dan seminar yang dapat membantu guru untuk belajar bagaimana cara mengembangkan multimedia interaktif untuk pembelajaran. Sesuai dengan pendapat dari (Rahmat, 2016) untuk meningkatkan keterampilan multimedia dan TIK untuk pelatih, seperti dengan meningkatkan kursus teknis dan keterampilan komputer multimedia seperti kursus intensif, lokakarya dan sejenisnya untuk menghasilkan perangkat lunak multimedia mereka sendiri yang terkait dengan subyek sedang diajarkan. Setelah guru mengikuti pelatihan dan seminar, maka diharapkan guru dapat mengembangkan multimedia interaktif untuk digunakan dalam pembelajaran.

Penggunaan multimedia interaktif dirasa efektif untuk bisa digunakan membantu siswa dalam memberikan pemahaman materi aksara Jawa yang dirasa sulit dan rumit. Sesuai dengan hasil penelitian dari (Sa'dun. Akbar, 2016) bahwa multimedia interaktif yang dimaksudkan dapat untuk memberikan alternatif dalam upaya untuk memenuhi kebutuhan belajar siswa, yang paling utama dalam kebutuhan media pembelajaran yang dapat memperjelas materia, meningkatkan minat, keaktifan, dan hasil belajar yang diperoleh siswa. Multimedia interaktif yang telah memanfaatkan teknologi informasi dan komunikasi dapat sangat amat membantu dalam proses terwujudnya pembelajaran yang dapat menarik perhatian siswa. Hal tersebut diperkuat dengan hasil penelitian dari (Yusra, 2016) multimedia dapat membantu siswa untuk menafsirkan dan memvisualisasikan ide dan konsep, itu akan memungkinkan siswa untuk terlibat langsung, serta meningkatkan motivasi dan pemahaman pembelajaran mereka.

Pembelajaran yang menggunakan multimedia interaktif merupakan kombinasi dari tiga unsur, yaitu suara, gambar, dan tulisan. Dengan menggunakan multimedia interaktif dirasa mampu memberikan rangsangan bagi otak dan indra dari siswa sehingga dapat mempermudah dan meningkatkan motivasi dalam belajar. Hal tersebut sejalan dengan pendapat dari (Hanim, 2016). Dengan siswa menggunakan multimedia siswa dapat melihat, mendengar dan bahkan berinteraksi sehingga keterlibatan indera siswa pada saat penggunaan multimedia pembelajaran yang interaktif lebih banyak dibandingkan daripada hanya menggunakan buku teks dan gambar biasa saja. Penggunaan media multimedia interaktif membuat siswa menjadi lebih tertarik dan aktif dalam belajar.

Selain itu, di SDN Kebonsari 2 Malang sudah terdapat sarana yang baik dan terdapat prasarana yang mendukung penggunaan media interaktif. Sarana prasarana terdapat di SDN Kebonsari 2 Malang salah satunya yaitu terdapat laboratorium komputer yang dapat digunakan oleh siswa. Fasilitas laboratorium komputer tersebut dapat mendukung penggunaan multimedia interaktif aksara Jawa. Siswa dapat menggunakan komputer yang disediakan sekolah untuk belajar dengan multimedia interaktif yang disediakan. Dengan demikian, diharapkan dapat menunjang kualitas pendidikan di sekolah.

Berdasarkan permasalahan yang telah dipaparkan diatas, maka peneliti mengembangkan multimedia interaktif aksara Jawa untuk sekolah dasar. Multimedia interaktif tersebut dapat digunakan sebagai media tambahan dalam belajar aksara Jawa. Sehingga dapat membantu siswa untuk belajar aksara Jawa secara menyenangkan dan menarik.

\section{METODE}

Pengembangan dalam penelitian yang satu ini termasuk ke dalam jenis Research \& Development (R\&D) yang memiliki tujuan menghasilkan produk dengan melalui beberapa prosedur atau langkah-langkah tertentu. Model Lee \& Owens (2014) memiliki lima langkah dalam pengembangan multimedia, yaitu (1) analisis kebtuhan (Need Assesment), (2) desain (design), (3) pengembangan (Development), (4) implementasi (Implentastion), dan (5) evaluasi (Evaluasion).

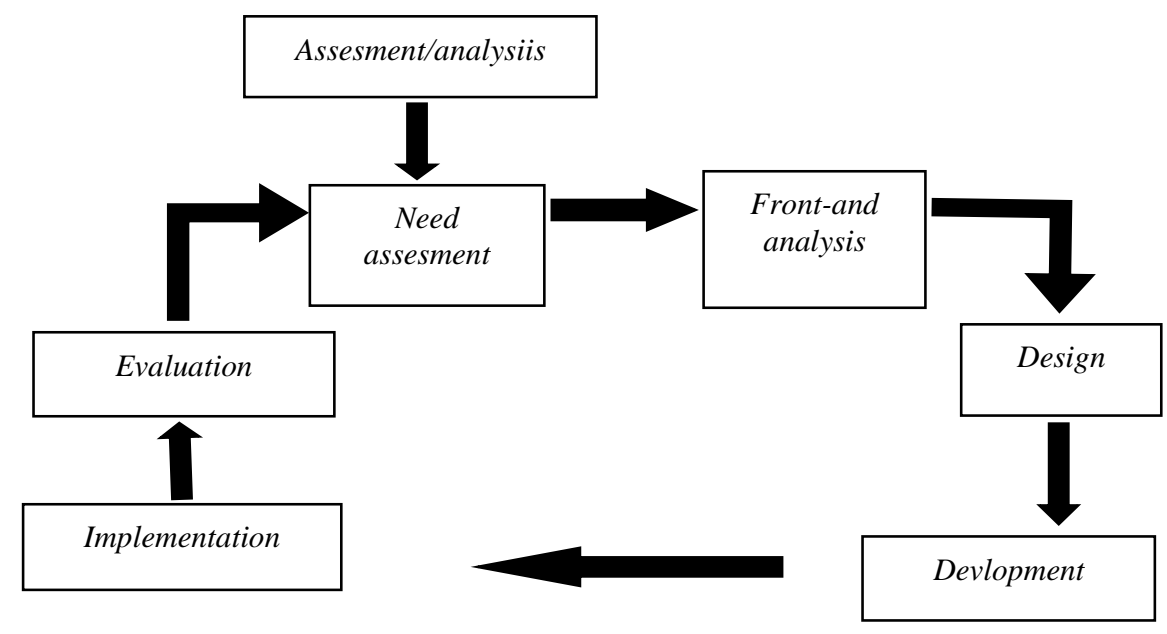

Gambar 1. Model Pengembangan Lee \& Owens 
Alasan dari pemilihan model yang ini adalah, yaitu (1) model Lee \& Owens merupakan salah satu model yang khusus digunakan untuk membuata desain pembelajaran berbasis multimedia oleh karena itu dapat mempermudah dalam melakukan pengembangan, (2) model Lee \& Owens memiliki beberapa langkah-langkah yang sistematis dan spesifik, terdapat tahap analisis, desain, pengembangan, penerapan, dan evalusi sehingga hasil penelitian dapat sesuai dengan tujuan yang diharapkan, (3) dalam model Lee \& Owens terdapat tahapan analisis kebutuhan dan analisis front-end yang tahap tersebut memiliki peranan penting dalam pelaksanaan proses penelitian pengembangan.

Tahap pertama penilaian/analisis, dalam tahap ini terbagi menjadi dua tahap, yaitu analisis kebutuhan dan analisis awalakhir. Analisis kebutuhan (Need Asessment) dilakukan dengan studi pendahuluan yang terdiri atas wawancara dan observasi lapangan. Analisis kebutuhan dilakukan untuk mengetahui kesenjangan antara kondisi nyata dengan kondisi yang diharapkan. Analisis awal-akhir meliputi analisis terhadap siswa, analisis teknologi yang tersedia, analisis situasi belajar, analisis tugas, analisis kejadian penting, analisis tujuan, analisis masalah, analisis media, analisis data yang ada, analisis biaya dan manfaat.

Tahap kedua adalah perencanaan, tahap ini peneliti membagi kegiatan memnjadi dalam dua tahap. Tahap yang pertama, yaitu melakukan perancangan untuk desain pembelajaran, peneliti menganalisis bahan materi muatan bahasa Jawa dengan materi aksara Jawa yang dimasukkan ke dalam bagian dari multimedia interaktif. Tahap yang kedua, yaitu melakukan perancangan untuk membuat media pembelajaran.

Tahap ketiga adalah pengembangan, pengembangan multimedia yang menurut Lee \& Owens (2014) dibagi menjadi tiga sub bagian utama yaitu Computer-based Multimedia, Web based Multimedia, dan Interactive distance-broadcast Multimedia. Pengembangan yang digunakan dalam penelitian ini adalah Computer-based Multimedia yang disesuaikan dengan analisis kebutuhan awal, keterbatasan waktu, dan biaya.

Tahap keempat adalah implementasi, tahap implementasi memiliki tujuan yaitu menerapkan multimedia interaktif yang telah divalidasi. Produk yang telah direvisi berdasarkan saran dan komentar ahli kemudian diujicobakan kepada siswa. Tahap selanjutnya adalah uji kelompok sedang. Setelah selesai, perlu dilakukan revisi sesuai dengan temuan yang ada. Tahap terakhir adalah uji lapangan terhadap siswa yang menjadi target pengguna produk yaitu seluruh siswa.

Tahap kelima adalah evaluasi, tahap ini adalah tahap terakhir dalam model Lee \& Owens. Evaluasi digunakan untuk mengetahui ketercapaian tujuan dalam pengembangan yang dilakukan. Evaluasi dilakukan dari beberapa sumber tidak hanya dari hasil belajar, namun juga berasal dari evaluasi formatif yaitu melakukan klasifikasi data yang dapat diperoleh dari para ahli dan uji coba dari pengguna. Setelah itu dapat disimpulkan apakah produk yang dikembangkan dapat mengatasi permasalahan yang ada dalam lapangan.

Desain uji coba dilakukan dalam dua tahapan, yaitu validasi ahli dan uji coba pengguna. Tahap pertama evaluasi ahli dilakukan oleh ahli untuk mengukur kevaliban peroduk. Uji coba ahli media dilakukan untuk mengukur kevalidan multimedia interaktif, sedangkan uji coba materi dilakukan untuk dapat mengetahui apakah sudah terdapat kesesuaian materi yang sudah terdapat dalam multimdia interaktif. Tahap kedua yaitu uji coba pengguna yaitu di lakukan kepada pengguna. Uji coba pengguna untuk dapat mengetahui tingkat kepraktisan, kemenarikan dan keefektifan produk multimedia interaktif . Uji coba kepada siswa dilakukan melalui dua tahap, yaitu uji coba kelompok sedang dan uji coba lapangan. Uji coba untuk kelompok sedang di lakukan kepada sembilan siswa kelas V dengan kriteria berprestasi tinggi, sedang, dan rendah. Berdasarkan uji coba kelompok sedang, dilakukan revisi untuk selanjutnya dilakukan uji lapangan.

Penelitian ini menggunakan dua tekenik anlisis data, yaitu tekenik anlisis deskriptif kualitatif dan aalisis deskriptif kuantitatif. Tekenik analisis deskriptif kualitatif digunakan untuk mengolah data. Teknik analisis data ini dilakukan dengan cara mengelompokkan informasi yang didapatkan dari data kualitatif berupa tanggapan, kritikan, dan saran perbaikan yang sudah disediakan dalam bentuk angket. Teknik analisis deskriptif kuantitatif digunakan untuk dapat menyajikan data hasil angket yang tersedia sehingga tercapai kesimpulan penelitian. Rumus yang digunakan untuk analisis data sebagai berikut:

Keterangan:

$$
\mathrm{V}=\frac{T s e}{T s h} \times 100 \%
$$

$\mathrm{V}=$ Validitas

$\mathrm{TSe}=$ Total sekor empirik validator

$\mathrm{TSh}=$ Sekor maksimal yang diharapkan (Sumber: Akbar, 2015)

Tabel 1. Kriteria Kevalidan, Kepraktisan, dan Kemenarikan

\begin{tabular}{lll}
\hline Kriteria Pencapaian & Tingkat Validitas & \multicolumn{1}{c}{ Keterangan } \\
\hline $85,01-100 \%$ & Sangat valid & Dapat digunakan tanpa perbaikan \\
\hline $70,01-85,00 \%$ & Valid & Dapat di gunakan nanun perlu perbaikan kecil \\
\hline $50,01-70,00 \%$ & Kurang valid & Disarankan tidak digunakan karena perlu revisi besar \\
\hline $01,00-50,00 \%$ & Tidak valid & Tidak boleh digunakan \\
\hline
\end{tabular}




\section{HASIL DAN PEMBAHASAN}

Hasil dari produk pengembangan ini menghasilkan multimedia interaktif aksara Jawa untuk sekolah dasar yang dikemas dalam CD/FD dilengkapi dengan buku petunjuk penggunaan untuk guru dan siswa. Materi yang terdapat dalam multimedia interaktif yaitu aksara carakan. Selain berisi materi, di dalam multimedia interaktif ini juga terdapat game edukasi yang dapat dimainkan oleh siswa. Siswa dapat belajar dengan sambil bermain dan bermain tetapi tetap sambil belajar. Dalam multimedia interaktif ini juga terdapat latihan soal dan evaluasi untuk mengetahui hasil dari belajar siswa menggunakan multimedia interaktif tersebut.

\section{Tayangan Pembuka}

Bagian awal multimedia interaktif adalah tampilan identitas dari siswa terdapat kolom nama dan gambar orang disampingnya. Siswa dapat menuliskan namanya pada kolom yang sudah disediakan. Setelah siswa mengisi namanya, tampilan selanjutnya yaitu masuk pada doa. Sebelum memulai belajar, siswa diajak untuk berdoa terlebih dahulu. Dalam tampilan ini, terdapat pilihan doa. Siswa dapat memilih doa mana yang akan mereka baca.
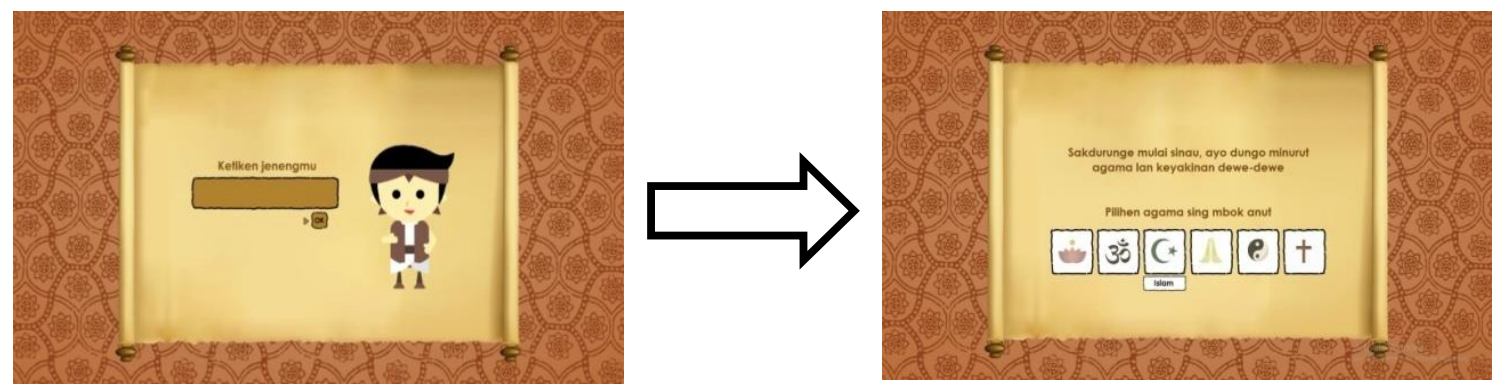

\section{Gambar 2. Tayangan Pembuka Multimedia Interaktif}

\section{Tampilan Utama}

Tampilan Utama (tampilan depan) berisi gambar dan menu lainnya dengan background batik. Gambar yang ada di tampilan home mencerminkan salah satu budaya dari Jawa. Dalam tampilan home terdapat menu sejarah, sinau, dolanan, dan evaluasi. Pada bagian atas terdapat tombol untuk menyalakan dan mematikan musik instrumental pengiring pembelajaran. Terdapat juga tombol profil pengembang, petunjuk, dan tombol untuk keluar.

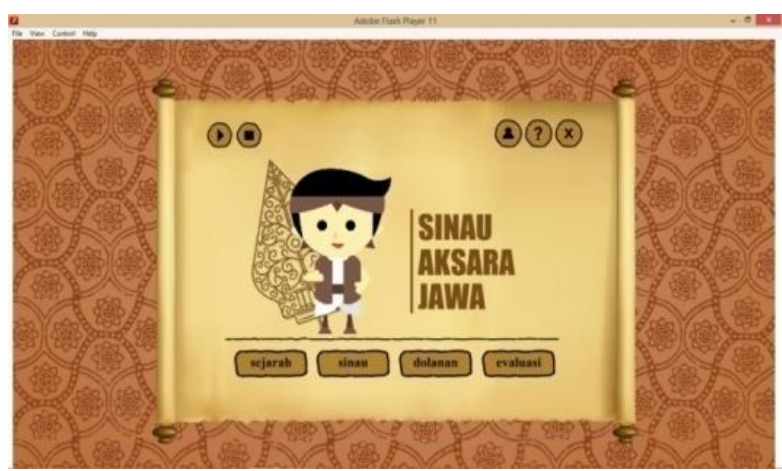

Gambar 3. Tampilan Utama Multimedia Interaktif

\section{Tampilan Petunjuk}

Tampilan petunjuk yaitu berisi keterangan masing-masing tombol yang tersedia pada multimedia interaktif. Penjelasan petunjuk dituliskan sederhana agar lebih mudah dipahami. Tampilan tombol akan ditata dan diletakkan berkumpul menjadi satu agar pandangan siswa lebih terarah. 


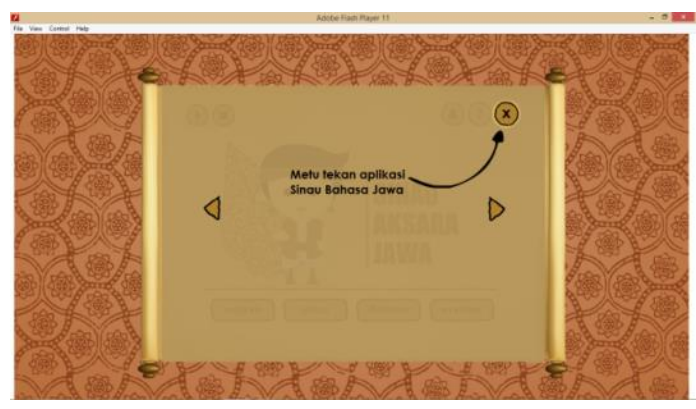

\section{Gambar 4. Tampilan Petunjuk Multimedia Interaktif}

\section{Tampilan Menu Sejarah}

Tampilan menu sejarah berisikan cerita asal usul aksara Jawa. Dalam cerita disertai dengan gambar yang mendukung cerita tersebut. Sehingga membantu siswa dalam memahami cerita tersebut.

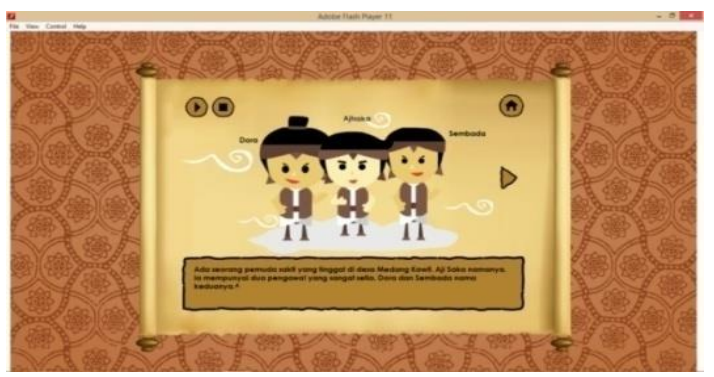

\section{Gambar 5. Tampilan Menu Sejarah}

\section{Tampilan Menu Sinau}

Tampilan menu sinau berisikan materi aksara jawa yang dibagi menjadi tiga bagian. Bagian pertama yaitu Sinau 1 berisikan aksara Jawa carakan, bagian kedua yaitu Sinau 2 berisikan sandhangan swara, bagian yang ketiga yaitu Sinau 3 berisikan materi.
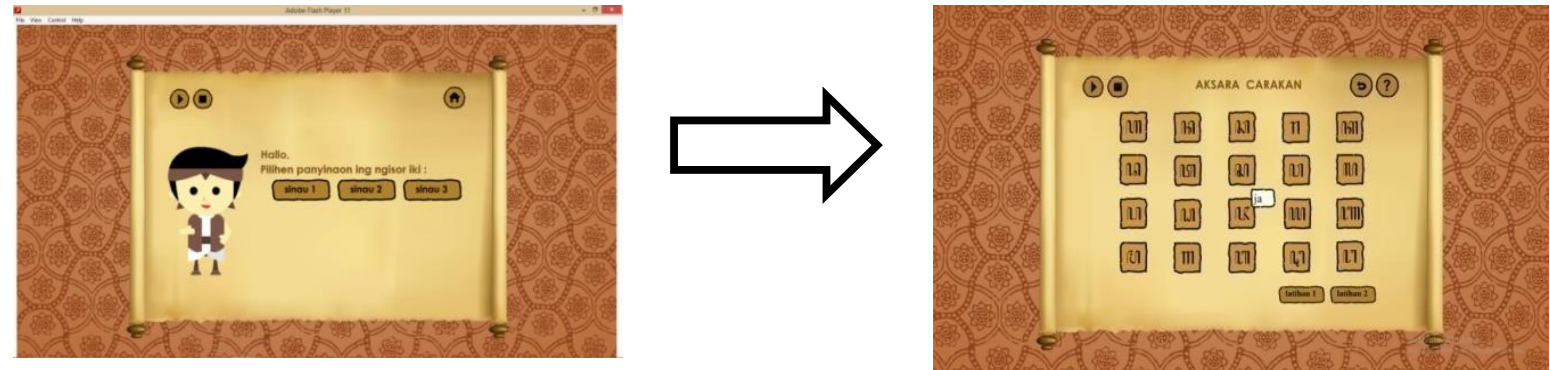

\section{Gamdar 6. Tampilan Menu Sinau}

\section{Tampilan Menu Dolanan}

Tampilan menu dolanan yang berisikan aksara Jawa carakan yang harus dijodohkan dengan tulisan latin yang sudah disediakan. Siswa dapat menarik aksara Jawa carakan tersebut dan ditempatkan diatas tulisan latin sesuai dengan aksara Jawa carakan yang dipilih. 


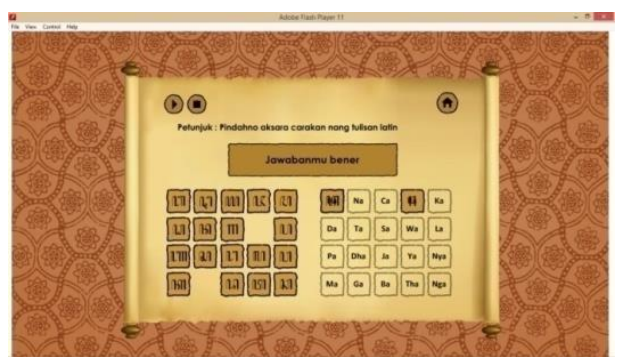

Gambar 7. Tampilan Menu Dolanan

\section{Tampilan Menu Evaluasi}

Tampilan menu evaluasi berisikan 10 soal aksara Jawa dengan jenis pilihan ganda. Diakhir evaluasi terdapat nilai dari evaluasi yang sudah dikerjakan. Setelah siswa selesai mengerjakan seluruh soal, maka muncul nilai yang diperoleh oleh siswa. Siswa dapat mengulangi mengerjakan evaluasi apabila nilai yang diperoleh dirasa masih kurang.

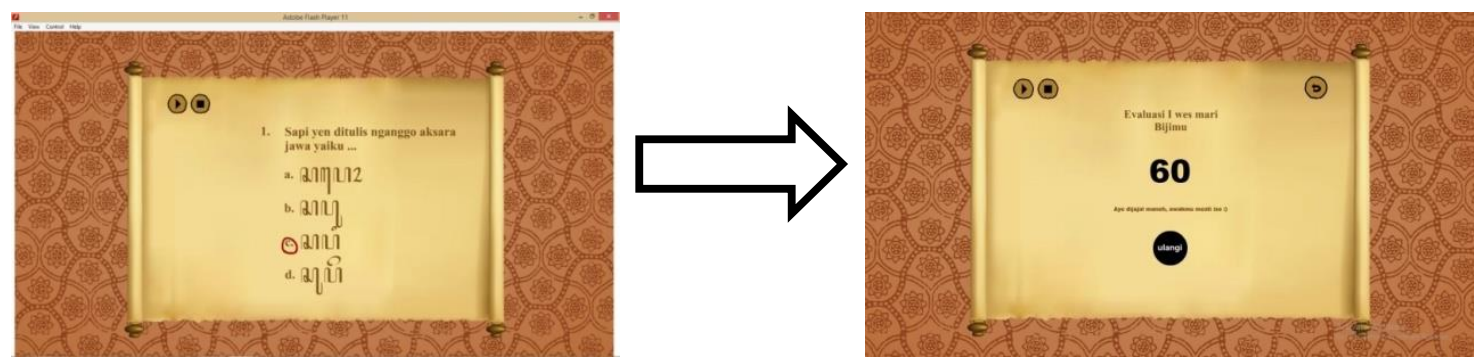

Gambar 8. Tampilan Menu evaluasi

\section{Tampilan Profil Pengembang}

Tampilan profil pengembang berisikan identitas diri dan contact person dari pengembang multimedia interaktif yaitu peneliti sendiri. Identitas diri meliputi nama, tempat tanggal lahir, alamat serta kontak pribadi pengembang. Terdapat foto pengembang multimedia interaktif untuk memperjelas identitas diri.

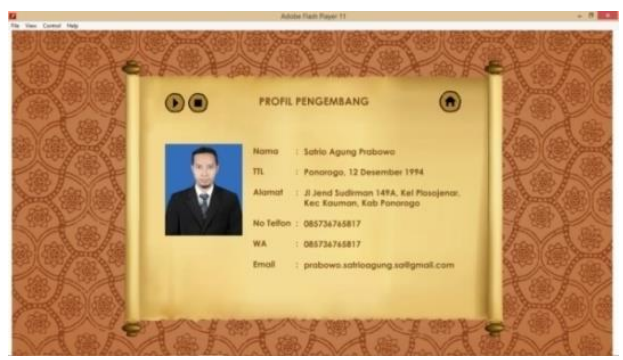

Gambar 9. Tampilan Profil Pengembang

Penentuan tingkat kevalidan multimedia interaktif dilakukan oleh ahli media dan ahli materi. Tabel 2 menyajikan hasil rekapitulasi hasil tingkat kevalidan multimedia interaktif.

Tabel 2. Rekapitulasi Hasil Validasi Ahli

\begin{tabular}{ccccc}
\hline No & Validasi & Persentase & Persentase Ideal & Keterangan \\
\hline 1 & Ahli Media & $86,36 \%$ & $100 \%$ & Sangat Valid \\
\hline 2 & Ahli Materi & $87,5 \%$ & $100 \%$ & Sangat Valid \\
\hline Jumlah & \multicolumn{5}{c}{$173,86 \%$} & $200 \%$ & \\
\hline Rata-rata & $86,93 \%$ & Sangat Valid \\
\hline
\end{tabular}


Tabel diatas menunjukkan bahwa hasil rekapitulasi hasil validasi ahli terhadap multimedia interaktif yaitu sebesar 86,93 $\%$ berada di rentang $85,01-100,00 \%$. Kriteria ini menunjukkan bahwa multimedia interaktif sangat valid sehingga layak untuk digunakan dalam pembelajaran bahasa Jawa materi aksara Jawa di sekolah dasar. Penentuan tingkat kepraktisan multimedia interaktif dilakukan oleh pengguna. Tujuannya untuk pengguna dapat mengetahui tingkat kemudahan pengguna dalam penggunaan multimedia interaktif dalam pembelajaran. Tabel 3 menyajikan hasil rekapitulasi hasil tingkat kepraktisan multimedia interaktif.

Tabel 3. Rekapitulasi Hasil Respon Pengguna

\begin{tabular}{ccccc}
\hline No & Sumber Data & Persentase Kepraktisan & Skor Ideal & Keterangan \\
\hline \multicolumn{4}{c}{ Uji Coba Kelompok Sedang } \\
\hline 1 & Guru & $78,57 \%$ & $100 \%$ & Praktis \\
\hline 2 & Siswa & $93,88 \%$ & $100 \%$ & Sangat Praktis \\
\hline \multicolumn{5}{c}{ Uji Coba Lapangan } \\
\hline 1 & Guru & $92,85 \%$ & $100 \%$ & Sangat Praktis \\
\hline 2 & Siswa & $94,02 \%$ & $100 \%$ & Sangat Praktis \\
\hline & Jumlah & $359,32 \%$ & $400 \%$ & \\
\hline & Rata-rata & $89,83 \%$ & Sangat Praktis \\
\hline
\end{tabular}

Tabel 3 menunjukkan bahwa hasil rekapitulasi hasil uji kepraktisan terhadap multimedia interaktif yaitu sebesar 89,83 $\%$ berada di rentang 85,01\% - 100,00 \%. Kriteria ini menunjukkan bahwa multimedia interaktif sangat praktis sehingga layak untuk digunakan dalam pembelajaran. Penentuan tingkat kemenarikan multimedia interaktif dilakukan oleh guru dan siswa. Tujuannya untuk mengetahui apakah multimedia interaktif dapat menimbulkan minat dan antusias belajar siswa. Tabel di bawah ini menyajikan rekapitulasi hasil tingkat kemenarikan multimedia interaktif.

Tabel 4. Rekapitulasi Hasil Respon Pengguna

\begin{tabular}{|c|c|c|c|c|}
\hline No & Sumber Data & Persentase Kemenarikan & Skor Ideal & Keterangan \\
\hline \multicolumn{5}{|c|}{ Uji Coba Kelompok Sedang } \\
\hline 1 & Guru & $80 \%$ & $100 \%$ & Menarik \\
\hline 2 & Siswa & $87,5 \%$ & $100 \%$ & Sangat Menarik \\
\hline \multicolumn{5}{|c|}{ Uji Coba Lapangan } \\
\hline 1 & Guru & $95 \%$ & $100 \%$ & Sangat Menarik \\
\hline 2 & Siswa & $93,40 \%$ & $100 \%$ & Sangat Menarik \\
\hline & Jumlah & $355,9 \%$ & $400 \%$ & \\
\hline & Rata-rata & $88,97 \%$ & & Sangat Menarik \\
\hline
\end{tabular}

Tabel diatas menunjukkan bahwa hasil rekapitulasi hasil uji kemenarikan terhadap multimedia interaktif yaitu sebesar $88,97 \%$ berada di rentang $85,01-100,00 \%$. Kriteria ini menunjukkan bahwa multimedia interaktif sangat menarik sehingga layak untuk digunakan dalam pembelajaran bahasa Jawa materi aksara Jawa di sekolah dasar. Data tingkat keefektifan berasal dari hasil siswa setelah selesai mengerjakan soal postes yang berjumlah ada sebanyak 10 soal dengan jenis pilihan ganda.

Tabel 5. Hasil Penilaian Pretes dan Postes

\begin{tabular}{cccc}
\hline No & Tes & Tuntas & Tidak Tuntas \\
\hline 1 & Pre Tes & 22 & 14 \\
\hline & Persentase Ketuntasan & \multicolumn{2}{c}{$61,11 \%$} \\
\hline 2 & Pos Tes & 33 & 3 \\
\hline & Persentase Ketuntasan & \multicolumn{2}{c}{$91,66 \%$} \\
\hline
\end{tabular}

Berdasarkan tabel 5 terlihat bahwa ada peningkatan nilai dari hasil nilai pre tes menunjukkan persentase ketuntasan siswa rata-rata mencapai $61,11 \%$, siswa yang mendapatkan nilai $\leq 70$ dengan keterangan tidak tuntas berjumlah 14 siswa dan 22 siswa mendapatkan nilai dengan keterangan tuntas. Hasil post tes menunjukkan persentase 91,66\% dengan kriteria "Sangat Efektif", hampir seluruh siswa mendapat kan nilai $\geq 70$ dengan keterangan tuntas. Hasil belajar siswa setelah menggunakan multimedia interaktif terlihat meningkat.

Multimedia merupakan penyampaian informasi melalui penggabungan lebih dari satu media (teks, gambar,video, audio maupun animasi) dan dikemas dalam bentuk digital. Menurut (Ariani, 2010) pengertian multimedia yaitu alat penyampaian pesan kepada publik yang didalamnya terdapat perpaduan dari berbagai media (format file) yang telah dikemas menjadi file digital 
(komputerisasi). Sedangkan menurut (Darmawan, 2013) multimedia yaitu pemanfaatan 'banyak' media yang digabung dalam suatu proses interaksi penyampaian pesan dari sumber kepada penerima, contohnya antara guru dan siswa. Menurut (Arsyad, 2006) pengertian multimedia yaitu kombinasi dari grafik teks suara video animasi yang merupakan kesatuan sehingga dapat menampilkan isi pelajaran.

Multimedia interaktif memiliki banyak kelebihan yang dapat membantu siswa dan guru dalam pembelajaran. Pengguna dapat berinteraksi langsung dengan media, mempermudah dalam penyampaian materi, tampilan lebih menarik, efisiensi dalam waktu dan tenaga. Menutut (Darmawan, 2014) melalui pembelajaran interaktif mampu mengaktifkan siswa untuk belajar dengan motivasi yang tinggi karena tampilan menarik pada sistem multimedia interaktif. Sedangkan dalam pembelajaran bahasa Jawa sendiri masih sangat kekurangan media pembelajaran. Siswa lebih antusias belajar apabila dalam pembelajaran terdapat media yang menarik. Menurut (Haryoko, 2013), Pembelajaran dengan komputer dapat membantu memahami materi tentang aksara Jawa, karena dengan komputer memungkinkan untuk menghadirkan bentuk pelajaran yang menaraik.

Multimedia interaktif yang dikembangkan ini memiliki manfaat diantaranya sebagai alternatif pemecahan masalah yang ada di sekolah, sebagai variasi media dalam pembelajaranbahasa Jawa khususnya dalam materi aksara Jawa yang masih sangat kekurangan dalam hal media pembelajaran. Selain itu dapat memotivasi siswa dan membantu siswa untuk memahami materi, meningkatkan semangat belajar tinggi, membantu melatih siswa belajar secara mandiri dan mengenal teknologi yang semakin berkembang. Multimedia interaktif ini juga dapat digunakan untuk memanfaatkan sarana yang tersedia agar sering digunakan dalam proses pembelajaran seperti LCD, proyektor, perangkat komputer.

Selain terdapat kelebihan dalam memanfaatan multimedia interaktif dalam proses pembelajaran, juga terdapat beberapa kekurangan. Pemanfaatan multimedia interaktif hada dapat digunakan apabila terdapat komputer atau laptop. Listrik atau daya juga harus tersedia jika akan memanfaatkan multimedia interaktif ini. Selain itu, dalam memanfaatkan multimedia interaktif interaksi antara guru dan siswa berkurang karena interaksi yang terjadi sebagian besar antara media dan siswa.

\section{SIMPULAN}

Multimedia interaktif telah layak digunakan dalam pembelajaran Bahasa Jawa di sekolah dasar karena telah terbukti dapat memenuhi kriteria kevalidan, kemenarikan, kepraktisan, dan keefektifan. Kevalidan dapat dilihat dari rata-rata persentase $86,93 \%$ dengan kriteria sangat valid. Kepraktisan multimedia interaktif dapat dilihat dari rata-rata persentase $89,83 \%$ dengan kriteria sangat praktis. Kemenarikan dapat dilihat dari rata-rata persentase 88,97\% dengan kriteria sangat menarik. Keefektifan multimedia interaktif didapat dari melihat perbedaan antara pretes dan postes. Terdapat peningkatan nilai siswa dari hasil nilai pretest menunjukkan persentase ketuntasan siswa rata-rata mencapai $61,11 \%$. Hasil posttest menunjukkan persentase $91,66 \%$ dengan kriteria "Sangat Efektif"

Berdasarkan hasil penelitian dan pengembanga multimedia interaktif aksara Jawa untuk sekolah dasar, pengembang memberikan saran sebagai berikut. Media ini dapat digunakan sebagai media pembelajaran secara individu, kelompok maupun klasikal dengan menayangkannya di LCD. Jika ditayangkan secara klasikal maka dibutuhkan speaker dan jika dioperasikan di laboratorium komputer maka diperlukan headset agar suara yang terdapat pada multimedia interaktif dapat terdengar. Sebelum mengoperasikan multimedia interaktif disarankan untuk membaca petunjuk penggunaan multimedia interaktif. Pengguna dapat menambahkan sumber belajar lain untuk dapat menunjang pemanfaatan multimedia Interaktif.

Penelitian pengembangan multimedia interaktif akasara Jawa untuk sekolah dasar tidak sampai pada tahap penyebaran (disseminate) dengan pertimbangan bahwa peneliti memiliki keterbatasan waktu dan biaya penelitian, selain itu masih dibutuhkan lagi kajian penelitian yang lebih mendalam. Namun, penyebaran dapat dilakukan sewaktu-waktu dengan memperhatikan kebutuhan dan kondisi lingkungan setempat.

Pihak sekolah dan peneliti dapat menjalin kerjasama dalam menyampaikan hasil penelitian ini untuk sekolah dasar ke sekolah lain melalui kelompok kerja guru, workshop, seminar, dan forum guru lainnya yang memungkinkan peneliti terlibat dalam pertemuan dengan pihak yang terkait sehingga multimedia interaktif aksara Jawa untuk sekolah dasar ini dapat diketahui dan dimanfaatkan oleh guru dan sekolah lain. Multimedia interaktif ini dapat disebarkan ke sekolah-sekolah dalam bentuk CD atau dapat di-copy dalam flashdisk. Namun, sebelum menyebarkan ke sekolah lain perlu disesuaikan dengan kondisi dan keadaan sekolah seperti karakteristik dan kebutuhan guru dan siswa, sarana dan prasarana. Produk Multimedia interaktif ini terbatas pada pembelajaran bahasa Jawa materi aksara Jawa untuk itu disarankan kepada pengembang lainnya untuk dapat membuat produk multimedia interaktif pembelajaran bahasa Jawa pada materi lain contohnya tembang dolanan dan imbuhan pada kata atau materi lain yang sesuai dengan kurikulum bahasa Jawa di sekolah dasar. 


\section{DAFTAR RUJUKAN}

Akbar, S. (2016). Optimize The Role of Schools in Building Character. Prosiding Seminar Internasional ICET-2. Malang: Malang: FIP UM.

Akbar, S. (2015). Instrumen Perangkat Pembelajaran. Bandung: Remaja Rosdakarya.

Arafik, M. (2013). Pembelajaran Bahasa Jawa di Sekolah Dasar Berbasis Karakter. Malang: Fakultas Ilmu Pendidikan Universitas Negeri Malang.

Ariani, N. (2010). Pembelajaran Multimedia di Sekolah: :Pedoman Pembelajaran Inspiratif,Konstruktif dan Prospektif. Jakarta: Prestasi Pustakaraya.

Arsyad, A. (2006). Media Pembelajaran. Jakarta: PT. Raja Grafindo Persada.

Badan Pusat Statistik. (2010). Kewarganegaraan Suku Bangsa, Agama, dan Bahsa Sehari-hari Penduduk Indonesia. Jakarta: Badan Pusat Statistik.

Batubara, H. H. (2015). Pengembangan Media Pembelajaran Interaktif pada Materi Operasi Bilangan Bulat. Madrasah Ibtidaiyah, 1(1), 1-12.

Darmawan, D. (2013). Teknologi Pembelajaran. Bandung: Remaja Rosdakarya.

Darmawan, D. (2014). Inovasi Pendidikan:Pendekatan Praktik Teknologi Multimedia dan Pembelajaran Online. Bandung: Remaja Rosdakarya.

Djuwadi. (2016). Pasinaon Basa Jawa: Edisi Jawa Timur. Kediri: Prima Putra Pratama.

Hanim, F., Sumarmi., \& Amiruddin, A.(2016). Pengaruh Penggunaan Multimedia Pembelajaran Interaktif. Jurnal Pendidikan: Teori, Penelitian, dan Pengembangan, 1(4), 752-757.

Haryoko, T. (2013). Pembuatan Media Pembelajaran Aksara Jawa pada Sekolah Dasar Negeri 2 Gunan Wonogiri. Jurnal Teknologi Informasi dan Komunikasi (JTIK) STMIK Provinsi Semarang, 4(1), 59-65.

Herijanto, B. (2012). Pengembangan CD Interaktif Pembelajaran IPS Materi Bencana Alam. Journal of Educational Social Studies, 1(1), 8-12.

Jusuf, H. (2009). Perancangan Aplikasi Sistem Ajar Tematik Berbasis Multimedia. Artificial, 3(1), 60-74.

Kusmayadi., Suyitno, I., \& Maryaeni. (2017). Pengembangan Multimedia Cerita Rakyat. Jurnal Pendidikan: Teori, Penelitian, dan Pengembangan, 2(7), 902-909.

Lee, William \& Owens, D. (2014). Multimedia-Based Instructional Design. In Igarss 2014 (Second). https://doi.org/10.1007/s13398-014-0173-7.2

Nurlaili, A. F., Suwignyo, H., \& Setyosari, P. (2016). Pengembangan Multimedia untuk Pengenalan Tokoh Wayang. Jurnal Pendidikan: Teori, Pnelitian, dan Pengembangan, 1(7), 1427-1431.

Rahmat, F. N. (2016). Multimedia for Teaching and Learning Among Trainers in TVET Institution. International Journal of Vocational Education and Training Research, 2(3), 18-23. https://doi.org/10.11648/j.ijvetr.20160203.11

Ramansyah, W. (2014). Pengembangan Multimedia Pembelajaran Interaktif Berbasis Adobe Flash Cs3 pada Kelas I SDN Bancaran 3 Bangkalan. Jurnal Ilmiah Edutic, 1(1), 1-11.

Tim Pengembang Kurikulum. (2010). Kurikulum Muatan Lokal Standar Kompetensi dan Kompetensi Dasar Mata Pelajaran Bahasa Sastra dan Budaya Lokal. Yogyakarta: Dinas Dikpora Provinsi DIY.

UU RI No. 20 Tahun 2003. (2003). Sistem Pendidikan Nasional (pp. 1-33). pp. 1-33.

Wiyoto, A. (2015). Peningkatan Motivasi dan Prestasi Belajar Bahasa Jawa Pada Siswa Kelas IX-D MTs N Kampak Trenggalek Menerapkan Pembelajaran dengan Multi Metode. Jurnal Pendidikan Profesional, 4(2), $190-201$.

Yusra, A. (2016). Multimedia Education Tools for Effective Teaching and Learning. Journal of Telecommunication, Electronic and Computer Engineering Figure, 9(2), 143-146. 